\title{
Flavobacterium defluvii sp. nov., isolated from activated sludge
}

\author{
Minjeong Park, ${ }_{1}^{1}$ Seung Hyun Ryu, ${ }^{1}$ Thu-Huong Thi Vu, ${ }^{1}$ Hyeon-Su Ro, ${ }^{2}$ \\ Pil-Yong Yun ${ }^{3}$ and Che Ok Jeon ${ }^{1}$ \\ ${ }^{1}$ Division of Applied Life Science, EB-NCRC, PMBBRC, Gyeongsang National University, Jinju \\ 660-701, Republic of Korea \\ ${ }^{2}$ Department of Microbiology and Research Institute of Life Science, Gyeongsang National \\ University, Jinju 660-701, Republic of Korea \\ ${ }^{3}$ Jeju Hi-Tech Industry Development Institute, 4-8 Ara-1 dong, Jeju 690-121, Republic of \\ Korea
}

Correspondence

Che Ok Jeon

cojeon@gnu.ac.kr

\begin{abstract}
A Gram-negative bacterium, designated strain EMB117 ${ }^{\top}$, was isolated from a municipal wastewater treatment plant and characterized by polyphasic taxonomy. The cells were non-spore-forming rods that showed gliding motility. Optimal growth occurred at $25-30{ }^{\circ} \mathrm{C}$ and $\mathrm{pH}$ 7.0-8.0. Strain EMB117 ${ }^{\top}$ contained phosphatidylethanolamine as the predominant polar lipid, and the major fatty acids were iso- $\mathrm{C}_{15: 0}$, iso- $\mathrm{C}_{17: 0} 3-\mathrm{OH}$, iso- $\mathrm{C}_{15: 0} 3-\mathrm{OH}$ and summed feature $3\left(\mathrm{C}_{16: 1} \omega 7 \mathrm{c}\right.$ and/or iso- $\left.\mathrm{C}_{15: 0} 2-\mathrm{OH}\right)$. The $\mathrm{G}+\mathrm{C}$ content of the genomic DNA was $33.5 \mathrm{~mol} \%$ and the major isoprenoid quinone was MK-6. A phylogenetic analysis based on 16S rRNA gene sequences showed that strain EMB117 ${ }^{\top}$ belonged to the genus Flavobacterium and was most closely related to Flavobacterium johnsoniae DSM $425^{\top}$ (97.8\% sequence similarity). The DNA-DNA relatedness between strain EMB $117^{\top}$ and $F$. johnsoniae ATCC $17061^{\top}$ was about $18 \%$. On the basis of the phenotypic, chemotaxonomic and molecular data, strain EMB117 ${ }^{\top}$ represents a novel species within the genus Flavobacterium, for which the name Flavobacterium defluvii sp. nov. is proposed. The type strain is EMB117 ${ }^{\top}\left(=\operatorname{KCTC} 12612^{\top}=\mathrm{DSM} 17963^{\top}\right)$.
\end{abstract}

Since the description of the genus Flavobacterium was emended by Bernardet et al. (1996), many additional Flavobacterium species have been described from diverse environmental habitats, such as microbial mats from Antarctic lakes, freshwater, seawater, sea ice, soil, the gut of an earthworm, sediments and wastewater treatment plants (McCammon \& Bowman, 2000; Van Trappen et al., 2002; Zhu et al., 2003; Horn et al., 2005; Kim et al., 2006; Yi \& Chun, 2006). Their physiological characteristics are also very diverse: they can be psychrophilic, psychrotolerant or mesophilic, they can be halotolerant, halophilic or sensitive to salts and they produce a variety of enzymes (Humphry et al., 2001; Tamaki et al., 2003; Aslam et al., 2005). Hence, the genus Flavobacterium may have diverse environmental functions. Recently, a novel Gram-negative bacterium, designated strain EMB $117^{\mathrm{T}}$, was isolated from activated sludge from a domestic wastewater treatment plant. On the basis of phenotypic and phylogenetic investigations,

The GenBank/EMBL/DDBJ accession number for the $16 \mathrm{~S}$ rRNA gene sequence of strain EMB $117^{\top}$ is DO372986.

A transmission electron micrograph of cells of strain EMB $117^{\top}$ is available as a supplementary figure in IJSEM Online.
EMB $117^{\mathrm{T}}$ represents a novel species in the genus Flavobacterium.

Strain EMB $117^{\mathrm{T}}$ was isolated from activated sludge from a domestic wastewater treatment plant in Pohang, Korea. The sludge sample was diluted serially with $1 \%(\mathrm{w} / \mathrm{v})$ saline solution and spread on R2A (Difco) agar at $20{ }^{\circ} \mathrm{C}$ for 2 days. Subculturing was done using R2A agar at $30^{\circ} \mathrm{C}$ for 1 day.

Sequencing of the 16S rRNA gene was carried out as described previously (Lane, 1991). The resulting 16S rRNA gene sequence (1436 nt) of strain EMB $117^{\mathrm{T}}$ was compared with $16 \mathrm{~S}$ available rRNA gene sequences (from GenBank), using the BLAST program (http://www.ncbi.nlm.nih.gov/ blast/) to determine an approximate phylogenetic affiliation; gene sequences were aligned with those of closely related species using CLUSTAL W software (Thompson et al., 1994). Phylogenetic trees were constructed using the neighbour-joining, maximum-likelihood and maximumparsimony algorithms available in PHYLIP software, version 3.6 (Felsenstein, 2002). The values for sequence similarity between the novel strain and related members of the genus Flavobacterium were computed using SIMILARITY MATRIX, version 1.1 (Ribosomal Database Project II; http:// 35.8.164.52/html/; Cole et al., 2003). A bootstrap analysis 
was performed according to the Kimura two-parameter model (Kimura, 1980) of the neighbour-joining method in the PHYLIP package. The phylogenetic analysis based on $16 \mathrm{~S}$ rRNA gene sequences indicated that strain $\mathrm{EMB} 117^{\mathrm{T}}$ formed a phyletic lineage with Flavobacterium johnsoniae DSM $425^{\mathrm{T}}$ with a relatively low bootstrap value $(62.0 \%)$ (Fig. 1). The overall tree topology of the neighbourjoining tree was supported by the maximum-likelihood and maximum-parsimony trees (data not shown). Comparative 16S rRNA gene sequence analyses showed that the isolate was most closely related to $F$. johnsoniae DSM $425^{\mathrm{T}}$, with a $16 \mathrm{~S}$ rRNA gene sequence similarity of $97.8 \%$; the sequence similarities with respect to other Flavobacterium species were less than $97.0 \%$.

DNA-DNA hybridization was carried out to evaluate the genomic DNA relatedness between strain $\mathrm{EMB} 117^{\mathrm{T}}$ and $F$. johnsoniae ATCC $17061^{\mathrm{T}}$. Extracted genomic DNAs were fragmented with HaeIII for slot hybridization (Lim et al., 2005). Digested DNAs were diluted serially and loaded into slots, with three replications, and each DNA was used individually as a labelled DNA probe for cross-hybridization. Random primed DNA labelling with digoxigenindUTP and hybridization (hybridization at $40{ }^{\circ} \mathrm{C}$; washing at $60^{\circ} \mathrm{C}$ ) were performed using the DIG High Prime DNA labelling kit (Roche Applied Science) according to the manufacturer's instructions and standard procedures (Sambrook \& Russell, 2001; Lim et al., 2005). Signals from the series of dilutions were quantified using GelDoc scanning software (Bio-Rad). The signals produced by selfhybridization were inferred as representing $100 \%$, and relatedness values (percentages) were calculated from triplicate samples. The DNA-DNA relatedness between

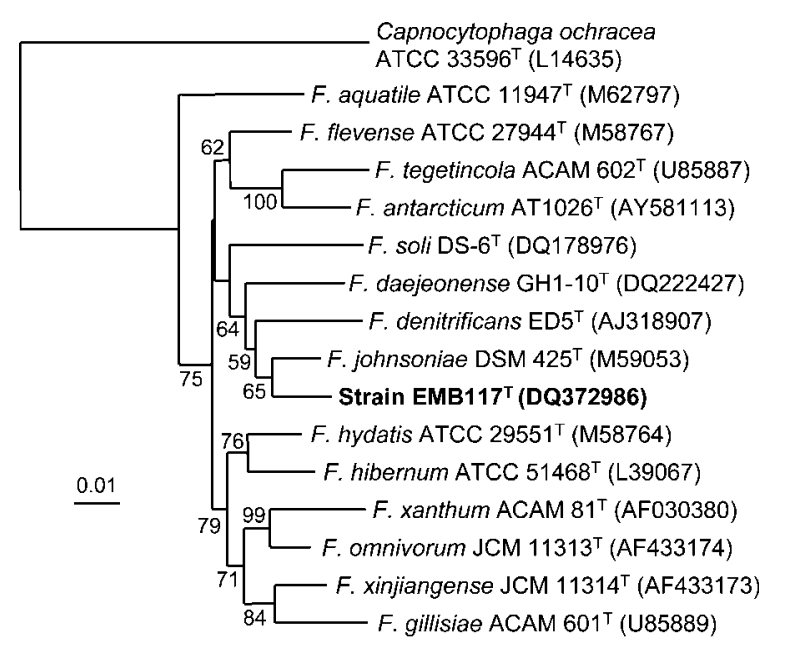

Fig. 1. Neighbour-joining phylogenetic tree, based on $16 \mathrm{~S}$ rRNA gene sequences, showing the phylogenetic relationships of strain $E M B 117^{\top}$ and related taxa. Bootstrap values are shown as percentages of 1000 replicates, when greater than $50 \%$. Capnocytophaga ochracea ATCC $33596^{\top}$ was used as an outgroup. Bar, 0.01 changes per nucleotide position. strain EMB $117^{\mathrm{T}}$ and F. johnsoniae ATCC $17061^{\mathrm{T}}$ was about $18 \%$, clearly below the $70 \%$ threshold generally accepted for species delineation (Stackebrandt et al., 2002).

The DNA G + C content of strain EMB $117^{\mathrm{T}}$, determined using HPLC apparatus fitted with a reversed-phase column (GROM-SIL 100 ODS-2FE; Grom) according to the method of Tamaoka \& Komagata (1984), was found to be $33.5 \mathrm{~mol} \%$.

Analysis of the fatty acid methyl esters was performed according to the instructions of the Microbial Identification System (MIDI; Microbial ID). Analyses of polar lipids and isoprenoid quinones were carried out using the methods described by Komagata \& Suzuki (1987). The cellular membrane contained iso- $\mathrm{C}_{15: 0}(19.8 \%)$, iso- $\mathrm{C}_{17: 0} 3-\mathrm{OH}$ (13.1\%), iso- $\mathrm{C}_{15: 0} 3-\mathrm{OH}(11.2 \%)$, iso- $\mathrm{C}_{15: 1} \mathrm{G}(7.6 \%)$, $\mathrm{C}_{15: 0}(6.4 \%)$ and summed feature $3\left(\mathrm{C}_{16: 1} \omega 7 \mathrm{c}\right.$ and/or iso$\left.\mathrm{C}_{15: 0} 2-\mathrm{OH}, 10.1 \%\right)$ as the major fatty acids. The polar lipid composition was dominated by phosphatidylethanolamine. The major respiratory lipoquinone of strain $\mathrm{EMB} 117^{\mathrm{T}}$ was MK-6. The fatty acid composition, the major lipoquinone and polar lipid and the DNA $\mathrm{G}+\mathrm{C}$ content of strain EMB $117^{\mathrm{T}}$ are in accordance with those of members of the genus Flavobacterium (Bernardet et al., 2002; Van Trappen et al., 2004, 2005; Aslam et al., 2005; Wang et al., 2006; Yoon et al., 2006).

Gram staining was performed using a bioMérieux Gramstain kit according to the manufacturer's instructions. Cell morphology, flagellation and gliding motility were studied using phase-contrast microscopy and transmission electron microscopy (JEM-1010; JEOL) as described previously (Bernardet et al., 2002; Jeon et al., 2005). The physiological characteristics of strain $\mathrm{EMB} 117^{\mathrm{T}}$ were examined by growing the isolate in $\mathrm{R} 2 \mathrm{~A}$ broth at various temperatures and $\mathrm{pH}$ values. $\mathrm{R} 2 \mathrm{~A}$ media with different $\mathrm{pH}$ values were prepared as described previously (Gomori, 1955). Salt tolerance was tested using R2A broth supplemented with $0-3 \%(\mathrm{w} / \mathrm{v}) \mathrm{NaCl}$ for 5 days at $30^{\circ} \mathrm{C}$. Duplicate antibiotic tests were performed using the diffusion method on R2A agar at $30^{\circ} \mathrm{C}$ with filter-paper discs $(8 \mathrm{~mm}$ diameter) containing the following antibiotics: ampicillin $(10 \mu \mathrm{g})$, polymyxin B $(100 \mathrm{U})$, streptomycin $(50 \mu \mathrm{g})$, penicillin $\mathrm{G}$ (10 IU), chloramphenicol $(100 \mu \mathrm{g})$, gentamicin $(30 \mu \mathrm{g})$, tetracycline $(30 \mu \mathrm{g})$, kanamycin $(30 \mu \mathrm{g})$, lincomycin $(15 \mu \mathrm{g})$, oleandomycin $(15 \mu \mathrm{g})$, neomycin $(30 \mu \mathrm{g})$, carbenicillin $(100 \mu \mathrm{g})$ and novobiocin $(50 \mu \mathrm{g})$. The diameters of inhibition zones were measured after 2 days. Oxidase activity was tested by determining the oxidation of $1 \%$ $(\mathrm{w} / \mathrm{v})$ tetramethyl- $p$-phenylenediamine (Merck) and catalase activity was evaluated by determining the production of oxygen bubbles in a $3 \%(\mathrm{v} / \mathrm{v})$ aqueous hydrogen peroxide solution. The production of flexirubin-type pigments and extracellular glycans was investigated using the $\mathrm{KOH}$ and the Congo red tests, respectively, according to the minimal standards for the description of novel taxa in the family Flavobacteriaceae (Bernardet et al., 2002). The hydrolysis of casein, gelatin, Tweens 80 and 20, aesculin, urea, tyrosine, 
starch and carboxylmethylcellulose was investigated on R2A agar after 7 days incubation, according to methods described previously (Lanyi, 1987; Gerhardt et al., 1994). Nitrate reduction was determined according to the method of Lanyi (1987), and acid production from carbohydrates was tested as described by Leifson (1963). Additional enzymic activities and biochemical features were determined using API ZYM and API 20E kits (bioMérieux) at $30{ }^{\circ} \mathrm{C}$. Growth under anaerobic conditions was determined in an anaerobic chamber $\left(\mathrm{H}_{2} / \mathrm{CO}_{2} / \mathrm{N}_{2}, 5: 10: 85\right)$ at $30^{\circ} \mathrm{C}$ on R2A agar.

Anaerobic growth was not observed after 7 days at $30{ }^{\circ} \mathrm{C}$ on R2A agar, but the strain showed weak growth after 16 days. As strain $\mathrm{EMB} 117^{\mathrm{T}}$ did not reduce nitrate to nitrite, it was unable to grow by anaerobic respiration using nitrate or nitrite as an electron acceptor, as reported for Flavobacterium denitrificans (Horn et al., 2005) and some F. johnsoniae strains (Stanier, 1947). Consequently, strain EMB $117^{\mathrm{T}}$ probably grew anaerobically by fermenting carbohydrates, as reported for Flavobacterium hydatis (Strohl \& Tait, 1978) and Flavobacterium succinicans (Anderson \& Ordal, 1961).

The phenotypic features of strain $\mathrm{EMB} 117^{\mathrm{T}}$ are presented in the species description. Strain $\mathrm{EMB} 117^{\mathrm{T}}$ showed the characteristics typical of members of the genus Flavobacterium (Bernardet et al., 2002) but could be differentiated from related Flavobacterium species by means of a number of traits, which are listed in Table 1. The physiological, biochemical and phylogenetic data support the description of strain $\mathrm{EMB} 117^{\mathrm{T}}$ as the type strain of a novel species within the genus Flavobacterium, for which the name Flavobacterium defluvii sp. nov. is proposed.

\section{Description of Flavobacterium defluvii sp. nov.}

Flavobacterium defluvii (de.flu'vi.i. L. gen. n. defluvii of sewage).

Cells are Gram-negative, non-spore-forming rods, 0.4-0.5 $\mu \mathrm{m}$ wide and 2.3-6.5 $\mu \mathrm{m}$ long. Some cells show a knar (see Supplementary Fig. S1 available in IJSEM Online). Cells are devoid of flagella, but gliding motility is observed. Colonies on R2A agar are pale yellow, glistening, translucent, slightly sticky, irregular, slightly raised and have curled margins. Grows at $10-40{ }^{\circ} \mathrm{C}$ (optimum, $25-30{ }^{\circ} \mathrm{C}$ ) and at pH 5.0-10.0 (optimum, pH 7.0-8.0). Grows optimally in plain R2A broth (no added $\mathrm{NaCl}$ ) and in R2A broth to which $1 \%(\mathrm{w} / \mathrm{v}) \mathrm{NaCl}$ has been added. Growth in $\mathrm{R} 2 \mathrm{~A}$ broth is severely inhibited by the addition of more than $2 \%(\mathrm{w} / \mathrm{v})$ $\mathrm{NaCl}$. Grows at $30^{\circ} \mathrm{C}$ on R2A agar, Luria-Bertani agar, tryptic soy agar (Difco) and nutrient agar (Difco). Grows well under aerobic conditions. Growth is weak and delayed under anaerobic conditions. Catalase-positive and oxidasenegative. Nitrate is not reduced to nitrite. Casein, Tween 20, urea, aesculin, gelatin and carboxylmethylcellulose are hydrolysed. Tween 80, tyrosine and starch are not hydrolysed. Congo red is not adsorbed by colonies, and
Table 1. Differential characteristics of strain $\mathrm{EMB} 117^{\top}$ and related Flavobacterium species

Taxa: 1, strain $\mathrm{EMB} 117^{\mathrm{T}} ; 2, F$. johnsoniae (data from Bernardet et al., 1996); 3, F. denitrificans (Horn et al., 2005); 4, F. soli (Yoon et al., 2006); 5, F. daejeonense (Kim et al., 2006); 6, F. aquatile (Bernardet et al., 1996). Symbols: +, positive; -, negative; d, variable among strains; $\mathrm{V}$, variable among references according to Bernardet et al. (1996); (+), weakly positive; NA, no data available.

\begin{tabular}{|lcccccc|}
\hline Characteristic & $\mathbf{1}$ & $\mathbf{2}$ & $\mathbf{3}$ & $\mathbf{4}$ & $\mathbf{5}$ & $\mathbf{6}$ \\
\hline Facultative anaerobe & $(+)$ & $\mathrm{d}$ & + & - & - & - \\
Growth on nutrient agar & + & + & + & + & + & - \\
Gliding motility & + & + & $\mathrm{NA}$ & - & + & + \\
Flexirubin-type pigments & + & + & + & - & - & - \\
Acid from carbohydrate & + & + & - & - & + & + \\
Congo red adsorption & - & $\mathrm{V}$ & $\mathrm{NA}$ & - & - & - \\
Degradation of: & & & & & & \\
$\quad$ Gelatin & + & + & $\mathrm{NA}$ & + & - & $\mathrm{V}$ \\
$\quad$ Casein & + & + & $\mathrm{NA}$ & - & - & + \\
$\quad$ Starch & - & + & $\mathrm{NA}$ & - & + & $\mathrm{V}$ \\
$\quad$ Carboxylmethylcellulose & + & + & $\mathrm{NA}$ & - & - & - \\
$\quad$ Aesculin & + & + & $\mathrm{NA}$ & - & + & $\mathrm{V}$ \\
$\quad$ Tyrosine & + & + & $\mathrm{NA}$ & - & - & $\mathrm{V}$ \\
Brown pigment on tyrosine agar & - & $\mathrm{d}$ & $\mathrm{NA}$ & $\mathrm{NA}$ & $\mathrm{NA}$ & - \\
$\beta$-Galactosidase activity & $(+)$ & + & $\mathrm{NA}$ & - & + & $\mathrm{V}$ \\
Nitrate reduction & - & $\mathrm{d}$ & + & - & + & $\mathrm{V}$ \\
DNA G+C content (mol\%) & 33.5 & 35.2 & 35 & 36.9 & 35 & 33 \\
& & & & & & \\
\hline
\end{tabular}

flexirubin-type pigments are produced. Negative for indole, $\mathrm{H}_{2} \mathrm{~S}$ and acetoin production and for citrate utilization (API 20E). Produces acid from raffinose, D-glucose, myo-inositol, lactose, $\mathrm{L}$-arabinose, melibiose, $\mathrm{D}$-fructose, $\mathrm{D}$-galactose, $\mathrm{D}-$ mannose, D-mannitol and arbutin, but not from salicin. Produces alkaline phosphatase, leucine arylamidase, valine arylamidase, naphthol-AS-BI-phosphohydrolase, $\alpha$-glucosidase, $\beta$-glucosidase and $N$-acetyl- $\beta$-glucosaminidase in API ZYM kits, but does not produce esterase (C4), lipase (C14), cystine arylamidase, $\alpha$-chymotrypsin, $\alpha$-galactosidase, $\beta$-glucuronidase, $\alpha$-mannosidase or $\alpha$-fucosidase. Weak enzymic activities are observed for esterase lipase (C8), trypsin, acid phosphatase and $\beta$-galactosidase. Resistant to polymyxin B, ampicillin, gentamicin, kanamycin, lincomycin, oleandomycin, neomycin, carbenicillin and novobiocin. Sensitive to streptomycin, penicillin G, chloramphenicol and tetracycline. Phosphatidylethanolamine is the predominant polar lipid. The major isoprenoid quinone is MK-6. The cellular fatty acids are iso- $C_{15: 0}(19.8 \%)$, iso$\mathrm{C}_{17: 0} 3-\mathrm{OH}(13.1 \%)$, iso- $\mathrm{C}_{15: 0} 3-\mathrm{OH}(11.2 \%)$, iso- $\mathrm{C}_{15: 1} \mathrm{G}$ (7.6\%), $\mathrm{C}_{15: 0}(6.4 \%)$, iso- $\mathrm{C}_{16: 0} 3-\mathrm{OH}(5.6 \%), \mathrm{C}_{16: 0} 3-\mathrm{OH}$ $(4.5 \%)$, anteiso- $\mathrm{C}_{15: 0}(4.4 \%), \mathrm{C}_{17: 1} \omega 6 c(2.4 \%)$, iso- $\mathrm{C}_{16: 0}$ $(2.3 \%)$, iso- $\mathrm{C}_{17: 0} \omega 9 c(2.3 \%), \mathrm{C}_{15: 0} 3-\mathrm{OH}(1.9 \%), \mathrm{C}_{16: 0}$ (1.9\%), $\mathrm{C}_{17: 0} 3-\mathrm{OH}(1.0 \%)$, summed feature 2 (iso- $\mathrm{C}_{16: 1} \mathrm{I}$ and/or $\left.\mathrm{C}_{14: 0} 3-\mathrm{OH}, 1.2 \%\right)$, summed feature $3\left(\mathrm{C}_{16: 1} \omega 7 c\right.$ and/or iso- $\left.\mathrm{C}_{15: 0} 2-\mathrm{OH}, 10.1 \%\right)$ and traces $(<1 \%)$ of $\mathrm{C}_{15: 1} \omega 6 c$, iso- $\mathrm{C}_{14: 0}$ and $\mathrm{C}_{17: 1} \omega 8 c$. The DNA G $+\mathrm{C}$ content is $33.5 \mathrm{~mol} \%$ (HPLC). 
The type strain, EMB $117^{\mathrm{T}} \quad\left(=\mathrm{KCTC} \quad 12612^{\mathrm{T}}=\mathrm{DSM}\right.$ $17963^{\mathrm{T}}$ ), was isolated from sludge that performed enhanced biological phosphorus removal in a laboratory-scale sequencing batch reactor.

\section{Acknowledgements}

This work was supported by grants from MOST/KOSEF to the Environmental Biotechnology National Core Research Center (grant R15-2003-012-02002-0) and to the 21C Frontier Microbial Genomics and Application Center Program (grant MG05-0104-4-0), Ministry of Science and Technology, Korea. The first three authors were supported by scholarships from the BK21 program of the Ministry of Education and Human Resources Development in Korea.

\section{References}

Anderson, R. L. \& Ordal, E. J. (1961). Cytophaga succinicans sp. n., a facultatively anaerobic, aquatic myxobacterium. J Bacteriol 81, 130-138.

Aslam, Z., Im, W. T., Kim, M. K. \& Lee, S. T. (2005). Flavobacterium granuli sp. nov., isolated from granules used in a wastewater treatment plant. Int J Syst Evol Microbiol 55, 747-751.

Bernardet, J.-F., Segers, P., Vancanneyt, M., Berthe, F., Kersters, K. \& Vandamme, P. (1996). Cutting a Gordian knot: emended classification and description of the genus Flavobacterium, emended description of the family Flavobacteriaceae, and proposal of Flavobacterium hydatis nom. nov. (basonym, Cytophaga aquatilis Strohl and Tait 1978). Int J Syst Bacteriol 46, 128-148.

Bernardet, J. F., Nakagawa, Y. \& Holmes, B. (2002). Proposed minimal standards for describing new taxa of the family Flavobacteriaceae and emended description of the family. Int J Syst Evol Microbiol 52, 1049-1070.

Cole, J. R., Chai, B., Marsh, T. L., Farris, R. J., Wang, Q., Kulam, S. A., Chandra, S., McGarrell, D. M., Schmidt, T. M. \& other authors (2003). The Ribosomal Database Project (RDP-II): previewing a new autoaligner that allows regular updates and the new prokaryotic taxonomy. Nucleic Acids Res 31, 442-443.

Felsenstein, J. (2002). PHYLIP (phylogeny inference package), version 3.6a. Distributed by the author. Department of Genome Sciences, University of Washington, Seattle, USA.

Gerhardt, P., Murray, R. G. E., Wood, W. A. \& Krieg, N. R. (1994). Phenotypic characterization. In Methods for General and Molecular Bacteriology, pp. 607-654. Edited by P. Gerhardt. Washington, DC: American Society for Microbiology.

Gomori, G. (1955). Preparation of buffers for use in enzyme studies. Methods Enzymol 1, 138-146.

Horn, M. A., Ihssen, J., Matthies, C., Schramm, A., Acker, G. \& Drake, H. L. (2005). Dechloromonas denitrificans sp. nov., Flavobacterium denitrificans sp. nov., Paenibacillus anaericanus sp. nov. and Paenibacillus terrae strain $\mathrm{MH} 72, \mathrm{~N}_{2} \mathrm{O}$-producing bacteria isolated from the gut of the earthworm Aporrectodea caliginosa. Int J Syst Evol Microbiol 55, 1255-1265.

Humphry, D. R., George, A., Black, G. W. \& Cummings, S. P. (2001). Flavobacterium frigidarium sp. nov., an aerobic, psychrophilic, xylanolytic and laminarinolytic bacterium from Antarctica. Int J Syst Evol Microbiol 51, 1235-1243.

Jeon, C. O., Lim, J. M., Lee, J. M., Xu, L. H., Jiang, C. L. \& Kim, C. J. (2005). Reclassification of Bacillus haloalkaliphilus Fritze 1996 as Alkalibacillus haloalkaliphilus gen. nov., comb. nov. and the description of Alkalibacillus salilacus sp. nov., a novel halophilic bacterium isolated from a salt lake in China. Int J Syst Evol Microbiol 55, 1891-1896.

Kim, B. Y., Weon, H. Y., Cousin, S., Yoo, S. H., Kwon, S. W., Go, S. J. \& Stackebrandt, E. (2006). Flavobacterium daejeonense sp. nov. and Flavobacterium suncheonense sp. nov., isolated from greenhouse soils in Korea. Int J Syst Evol Microbiol 56, 1645-1649.

Kimura, M. (1980). A simple method for estimating evolutionary rates of base substitutions through comparative studies of nucleotide sequences. J Mol Evol 16, 111-120.

Komagata, K. \& Suzuki, K. (1987). Lipid and cell-wall analysis in bacterial systematics. Methods Microbiol 19, 161-208.

Lane, D. J. (1991). 16S/23S rRNA sequencing. In Nucleic Acid Techniques in Bacterial Systematics, pp. 115-175. Edited by E. Stackebrandt \& M. Goodfellow. Chichester: Wiley.

Lanyi, B. (1987). Classical and rapid identification methods for medically important bacteria. Methods Microbiol 19, 1-67.

Leifson, E. (1963). Determination of carbohydrate metabolism of marine bacteria. J Bacteriol 85, 1183-1184.

Lim, J. M., Jeon, C. O., Park, D. J., Kim, H. R., Yoon, B. J. \& Kim, C. J. (2005). Pontibacillus marinus sp. nov., a moderately halophilic bacterium from a solar saltern, and emended description of the genus Pontibacillus. Int J Syst Evol Microbiol 55, 1027-1031.

McCammon, S. A. \& Bowman, J. P. (2000). Taxonomy of Antarctic Flavobacterium species: description of Flavobacterium gillisiae sp. nov., Flavobacterium tegetincola sp. nov. and Flavobacterium xanthum sp. nov., nom. rev. and reclassification of [Flavobacterium] salegens as Salegentibacter salegens gen. nov., comb. nov. Int J Syst Evol Microbiol 50, 1055-1063.

Sambrook, J. \& Russell, D. W. (2001). Molecular Cloning: a Laboratory Manual, 3rd edn. Cold Spring Harbor, NY: Cold Spring Harbor Laboratory.

Stackebrandt, E., Frederiksen, W., Garrity, G. M., Grimont, P. A. D., Kämpfer, P., Maiden, M. C. J., Nesme, X., Rosselló-Mora, R., Swings, J. \& other authors (2002). Report of the ad hoc committee for the re-evaluation of the species definition in bacteriology. Int J Syst Evol Microbiol 52, 1043-1047.

Stanier, R. Y. (1947). Studies on nonfruiting myxobacteria. I Cytophaga johnsonae, n. sp., a chitin-decomposing myxobacterium. J Bacteriol 53, 297-315.

Strohl, W. R. \& Tait, L. R. (1978). Cytophaga aquatilis sp. nov., a facultative anaerobe isolated from the gills of freshwater fish. Int J Syst Bacteriol 28, 293-303.

Tamaki, H., Hanada, S., Kamagata, Y., Nakamura, K., Nomura, N., Nakano, K. \& Matsumura, M. (2003). Flavobacterium limicola sp. nov., a psychrophilic, organic-polymer-degrading bacterium isolated from freshwater sediments. Int J Syst Evol Microbiol 53, 519-526.

Tamaoka, J. \& Komagata, K. (1984). Determination of DNA base composition by reverse-phase high-performance liquid chromatography. FEMS Microbiol Lett 25, 125-128.

Thompson, J. D., Higgins, D. G. \& Gibson, T. J. (1994). CLUSTAL W: improving the sensitivity of progressive multiple sequence alignment through sequence weighting, position-specific gap penalties and weight matrix choice. Nucleic Acids Res 22, 4673-4680.

Van Trappen, S., Mergaert, J., Van Eygen, S., Dawyndt, P., Cnockaert, M. C. \& Swings, J. (2002). Diversity of 746 heterotrophic bacteria isolated from microbial mats from ten Antarctic lakes. Syst Appl Microbiol 25, 603-610.

Van Trappen, S., Vandecandelaere, I., Mergaert, J. \& Swings, J. (2004). Flavobacterium degerlachei sp. nov., Flavobacterium frigoris sp. nov. and Flavobacterium micromati sp. nov., novel psychrophilic bacteria isolated from microbial mats in Antarctic lakes. Int J Syst Evol Microbiol 54, 85-92. 
Van Trappen, S., Vandecandelaere, I., Mergaert, J. \& Swings, J. (2005). Flavobacterium fryxellicola sp. nov. and Flavobacterium psychrolimnae sp. nov., novel psychrophilic bacteria isolated from microbial mats in Antarctic lakes. Int J Syst Evol Microbiol 55, 769-772.

Wang, Z.-W., Liu, Y.-H., Dai, X., Wang, B.-J., Jiang, C.-Y. \& Liu, S.-J. (2006). Flavobacterium saliperosum sp. nov., isolated from freshwater lake sediment. Int J Syst Evol Microbiol 56, 439-442.
Yi, H. \& Chun, J. (2006). Flavobacterium weaverense sp. nov. and Flavobacterium segetis sp. nov., novel psychrophiles isolated from the Antarctic. Int J Syst Evol Microbiol 56, 1239-1244.

Yoon, J.-H., Kang, S.-J. \& Oh, T.-K. (2006). Flavobacterium soli sp. nov., isolated from soil. Int J Syst Evol Microbiol 56, 997-1000.

Zhu, F., Wang, S. \& Zhou, P. (2003). Flavobacterium xinjiangense sp. nov. and Flavobacterium omnivorum sp. nov., novel psychrophiles from the China No. 1 glacier. Int J Syst Evol Microbiol 53, 853-857. 